\title{
Ethnopolitical Tendencies in Lithuania During the Period 1905-1907 and the Conceptions of the Revival of the University of Vilnius
}

\author{
Darius STALIŪNAS
}

The period of 1905-1907 is remarkable in the early 20th-century Lithuanian history for its extraordinary liberalization of cultural and political life, which made it possible for various social strata to state their goals clearly. Therefore, when dealing with the issue of the need for the institute of a higher education it is not difficult to see, that over this period one or another part of society was more open, in comparison with 1900-1904 or the period immediately after 1907, in declaring its own concept of a higher school, taking less heed of the attitude of the Russian administration. During the revolution of 1905 most opinions were in favour of the revival of the University of Vilnius. In the context of the early part of the 20th century such a formulation is notable for several reasons. On the one hand, views are expressed in support of the need for a university adapted to the requirements of society, not the tsarist administration. On the other, the stipulation that the university is to be reopened rather than "founded" indicates the right of having a higher school results primarily from the fact that the nation had this type of institution before, i.e. this is a declaration of a historical right to have a university in Vilnius. This circumstance not only throws some new light on the legitimacy of this demand, it also presupposes another problem which could be labelled as the distribution of the legacy left by the University of Vilnius of the early 19 th century. The point is that by declaring the aim to restore the university one cannot avoid expressing an opinion that the contribution of the existing university to the cultural (and political) life of Lithuania. It was precisely because the Russian administration regarded the University of Vilnius in the early 19th century as a stronghold of polonization, that at the beginning of the 20th century, no public appeal for the foundation of a higher school at Vilnius was based on the fact that a university had already existed there. This problem, however, is not our present concern; it could be discussed in separate study.

There is no doubt that the revival of the University of Vilnius was only possible if the internal structure of the Russian empire underwent substantial changes. Therefore the question of the revival of the University of Vilnius is closely related with ethnopolitical tendencies in Lithuania. 
During the early part of the 20th century Lithuanian political organizations, such as the Lithuanian Democratic Party (LDP) and the Lithuanian Social Democratic Party (LSDP), cherished the idea of Lithuania's autonomy within its ethnographic boundaries. It was, however, not beyond the unit of these parties to raise the idea of Lithuania's political and cultural autonomy in the historic lands of the GDL, as a tactical (temporary) solution. The concept of autonomy within the historical (ethnographic) lands of Lithuania was developed even more explicitly at the Great Assembly of Vilnius by the newly arising National Democratic Party (TLDP) seeking to become a focus to unite all Lithuanian political forces. The TLDP became the leading political force in Lithuania during the election to the First Russian Duma. It was under the leadership of this party at the elections in the province of Kaunas that Lithuanians concluded a political alliance not with the Poles but with the Jews ${ }^{1}$. Naturally, this could hardly enhance the peaceful co-existence between Lithuanians and Poles.

Among the Polish citizens of Lithuania the National Democratic trend during the revolt of 1905 had not yet acquired any clearer institutional margins, although several individual Polish social activists can be mentioned. They propagated the ideas of the Polish National Democrats but at the same time they were still active in other organizations. During the elections they were notable as a political force probably only in the province of Suvalkai. The National Democrats treated the historic lands of the GDL as a Polish province, therefore the consolidation of polonicity in this territory was their main aim.

The Belorussians should not be considered an independent political force in the Revolt of 1905. The Jews' main objective was to obtain equal rights with the other peoples of the empire; seeking autonomy both in the lands of the GDL and in Lithuania proper was to them a tactical manoeuvre.

Alongside the aim to create political organizations which united members of only one or another nation, attempts were made to join together all inhabitants of the historic GDL lands. The consultations of the so-called Autonomist's Club in 1904-1905 can be viewed as a democratic version of such an attempt. At these conferences the democratically-oriented Lithuanian, Polish, Belorussian and Jewish activists tried to find solutions that would satisfy the people of all groups. A proper solution, however, was not found at these meetings, as the Lithuanians, unlike the other participants, only agreed with the demand for Lithuanian autonomy within its ethnographic boundaries, not the historic lands of the Grand Duchy. The main supporter of the political integration of the GDL historical lands was the Krajowcy democratic trend which, to tell the truth, only began to crystallize dur-

${ }^{1}$ D. Staliūnas, Rinkimai ị I Rusijos Dūmą Lietuvoje, in LIM, 1994, 55-56. 
ing the Revolt of 1905. During the Vilnius elections to the First Russian Duma one of its chief leaders - Tadeusz Wróblewski, was among the first to promote the idea of political integration among the peoples living in the historic lands of the GDL.

In the meantime, the bishop of Vilnius, Eduard von der Ropp, established the Lithuanian-Belorussian Constitutional Catholic Party (Pol.: Stronnictwo konstytucyjno katolickie na Litwę i Beloruś) in an attempt to unify the inhabitants of the historic lands of the GDL under the banner of Catholicism.

Having made a fairly schematic overview of the orientation of Lithuania's political forces, it is possible to assert not only that their key objective was to represent the different sections of the society, which goes without saying, but they also had a specific concept of Lithuania. It is obvious that various political forces were supposed to have a different perception of the aims of the re-established university. Yet, on the other hand, compromise is possible both in the area of political opportunities and in the reopening of the university.

We believe that it is possible to single out four concepts of the re-establishment (establishment) of the University of Vilnius: a Lithuanian university, a Polish university, the university of Lithuania and a university in Lithuania.

In their analysis of the re-opening of the university, historians place by far the heaviest emphasis on the idea of a "Free University" (Lith. Liuosas universitetas), developed by the Lithuanian and Polish intellectuals late in 1905. Usually attention is drawn to the signatories to the founding declaration "of a Free University society with teaching in Lithuanian, Polish, Russian and other national languages" with a brief review of the contents of the declaration. Some researchers add that it was "a certain tactical measure" . Among the papers that are most often mentioned in this respect are the Lithuanian memorandum to the Russian Prime Minister Count S. Vitte, various petitions, the demand of the Lithuanian Teacher's Association, which raised the question of the reopening of Vilnius University ${ }^{3}$. It is also pointed out in many cases that the intellectual foundations of the higher school were to be provided by the Lithuanian Learned Society (Lietuvos mokslo draugija, [LMD]) and the Association of Science Fellows (Pol. Towarzystwo przyjaciót nauk w Wilnie, Lith. Mokslo bičiuliu draugija $[\mathrm{MBD}])$, and some authors even assume that both associations had considered the question of reopening of Vilnius University more than once $^{4}$. Besides, Egidijus Aleksandravičius, researching attempts to re-

${ }^{2}$ V. Žukas, Iš Vilniaus universiteto atkürimo istorijos, Lietuvos TSR aukštujų mokyklu mokslo darbai. Pedagogika ir psichologija, VI, 1964, 116; Vilniaus universiteto istorija. 1803 1940, Vilnius, 1977, 139-140; Istonija Vilniuskogo universiteta (1579-1979), Vilnius, 1979, 135-136; E. Aleksandravičius, XIX amžiaus profiliai, Vilnius, 1993, 161; Vilniaus universiteto istorija. 1579-1994, Vilnius, 1994, 155.

${ }^{3}$ Ibid.; I.Ariskin, Shkola v Litve v epokhu kapitalizma, in Iz istorii shkoly Belorussii i Litvy, Moscow, 1964, 287.

${ }^{4}$ Vilniaus universiteto istorija. 1803-1940, 141; E. Aleksandravičius, op. cit., 162. 
vive a university in Lithuania, paid attention to the role of Kaunas as a potential centre of Lithuanian culture in the early 20th century. He believes that Kaunas "possessed a certain intellectual soil on which the seed of the university idea could also be sown" .

\section{A Lithuanian University}

We will start our discussion which is based on archival material and early 20th century newsprints, by reviewing the arguments on which the Lithuanians based their urgent demands for a university in Vilnius. Incidentally, it was mainly to a university and not some other type of a higher school that priority was usually given. During the Revolt of 1905 , as often in the late 19 th and early 20 th centuries, it was assumed that the establishment of a higher school at Vilnius would serve to gather a significant sector of Lithuanian youth which would increase the ranks of Lithuanian intelligentsia, because "those studying abroad often forget Lithuanian affairs". However, new emphases arose. The reopening of the University was also recognized as a symbolic act. For instance, Vilniaus žinios wrote in its coverage of a "Free university" (see below p. 104-110) that the foundation of such a university in Vilnius "was to provide political evidence for everyone that Lithuanian citizens had long been politically mature..."7. Another important point in this coverage emphasizes that "from the economical point of view such a university is equally important" .

The demand for the reopening (reestablishment) of Vilnius university became an integral part of most Lithuanian petitions. The urgency of the reopening of the university was formulated by the illegal Lithuanian Teachers' Association at its constituent assembly on July $30,1905^{\circ}$. A similar demand is found in the petition of the pupils of the Panevėžys real gymnasium on May 2, 1905 to the officer in charge of the Vilnius educational district; in the proclamation of the social democratic youth ${ }^{10}$, in the appeal to the Tsar made by Lithuanians resident in Riga $^{11}$, in a number of peasants' petitions ${ }^{12}$ and other documents. The same demand was formulated in the Lithuanian parties' programmes as well ${ }^{13}$.

The crucial point in this problem was the formulation of the idea of a (Lithuanian) university in the course of the revolt. It was

${ }^{5}$ E. Aleksandravičius, op. cit., 162.

${ }^{6}$ V. Karuža [J. Jasaitis], Universiteto Vilniuje reikia, Vilniaus žinios, 85, 1905; Pranas [P. Klimaitis], Mokslas ir apšvietimas - tai žmonių gerové, ibid., 247.

${ }^{7}$ K.P. [?], Vilniaus universitetas, ibid., 8, 1906.

${ }^{8}$ Ibid.

${ }^{9}$ Vilniaus universiteto istorija. 1803-1940, 139.

${ }^{10}$ Ibid.

${ }^{11}$ Rygos lietuvių prašymas, Vilniaus žinios, 74, 1905.

${ }^{12}$ A. Tyla, 1905 m. revoliucija Lietuvos kaime, Vilnius, 1968, 122.

${ }^{13}$ Tautiškosios lietuvių demokratų partijos dokumentai, red. R. Miknys, E. Motieka, in Lietuviu Atgimimo Istorijos studijos [LAIS], I:Tautines savimonès žadintojai: nuo asmens iki partijos, Vilnius, 1990, 194. 
asserted that the Lithuanian nation had already awakened, so it needed a national university, in the same way as other nations $\mathrm{did}^{14}$.

The climax of the revolt of 1905 was the Lithuanian congress at Vilnius (called by historians) - "the Great Assembly of Vilnius"), held on November 22-23, 1905 (all dates in this article are in the old style). Early in November 1905 before the assembly was convened, its initiators drafted a memorandum to the Chairman of the Council of Ministers S. von Witte, which also included a demand to establish the University of Vilnius: "The Lithuanians require free, universal and compulsory education in their mother tongue; the foundation of a sufficient number of elementary, secondary and higher schools (Vilnius University), which are closely connected, so that it will be possible to pass gradually from elementary to higher stages as well as to provide anyone with equal rights to establish such schools"15. At the Great Assembly of Vilnius issues concerning Lithuanian schools were heard in the fourth sitting. Egidijus Motieka argues that this question was among the few "that did not arouse any stronger disagreement" 16 However, the question of a university or some other higher schoool was not discussed separately at the Assembly.

Indeed the primary concern was the establishment of lowerlevel Lithuanian schools. Very early in 1905 "Vilniaus žinios" reported that the Lithuanians were going to appeal to the authorities for permission to set up at least one Lithuanian school in Vilnius ${ }^{17}$. One Lithuanian student, Zigmas Žemaitis, also suggested to start with Lithuanian schools in Vilnius ${ }^{18}$. Another of his suggestions was that the issue of Vilnius university should be finally resolved by the second Lithuanian Congress which was to meet in spring $1906^{19}$.

Another idea that is worth considering was developed by E. Aleksandravičius. He emphasized the role of Kaunas as a Lithuanian cultural centre of the early 20 th century. First, let us recall the arguments to this effect. Aleksandravičius believes that the Lithuanian cultural movement in Vilnius ran up against the opposition of the conservative nobility and the Polish NDs. In addition, the Lithuanian Christian democrats had not succeded in establishing an organizational centre in Vilnius (incidentally, Vilnius was also selected by the opponents of the Christian Democrats - the national trend). They focused their activities in Kaunas which had a theological seminary, more sizeable organizations of Catholic culture and educa1905.

${ }^{14}$ B.V. [A. Rucevičius], Rūpinkimès ịsteigti universitetą Vilniuje, Vilniaus žinios, 157,

${ }^{15}$ Lithuanian memorandum to the Russian Prime Minister Vitte (November, 1905), ed. E. Motieka, in LAIS, III: Lietuvos valstybés idejja (XIX a. - XX a. pradžia), Vilnius, 1991, 349.

${ }^{16}$ E.Motieka, Didysis Vilniaus Seimas, Unpublished Ph. D. thesis, University of Vilnius, 1993, 230 .

${ }^{17}$ Atbalsiai, Vilniaus žinios, 7, 1905.

${ }^{18} \mathrm{Z}$. Žemaitis, Prie Vilniaus universiteto, ibid., 23, 1906.

${ }^{19} \mathrm{Z}$. Žemaitis, Dar prie Vilniaus universiteto, ibid., 45 
tion. All this, in Aleksandravičius' opinion, created some intellectual soil "on which the seed of the university idea could fall some time later" $"$. And indeed, speculations about the role of Kaunas, as Lithuania's ethnical centre, did exist. Such a position was expressed namely in the Christian-Democratic Nedeldienio skaitymas (The Sunday Digest). The author, hiding under the pen name "Lithuanian grandpa" maintained that Kaunas held priority over Vilnius in that it enjoyed a greater Lithuanian political maturity, and that the Lithuanian positions here were consolidating (while in Vilnius they were getting weaker), besides, Kaunas had a firmer philosophical background: "The Kaunas press stands on the Christian foundation and breathes in the spirit of Christianity" and further on: "Vilnius is pressing the Kaunasites to separate and follow a totally independent - Christian - road"21. Antanas Smetona reacted to this with an article in Viltis ("Hope") headlined Vilnius - Lietuvos širdis (Vilnius - the Heart of Lithuania). Following this the superiority of Kaunas was stressed once more - "Nedeldienio skaitymas" published another article by the same author entitled "Kur dabartinès Lietuvos centras: Kaune ar Vilniuj?" (Where is the centre of modern Lithuania: Vilnius or Kaunas?). This publication sought in effect to confirm Kaunas as the centre of the ethnographic Lithuanian lands ${ }^{22}$. Similar ideas were not alien to the editors of the "Nedeldienio skaitymai" either: "By carrying this article of Lithuanian Grandpa we are not in the least opposed to the idea of Vilnius becoming the centre of Lithuania. On the contrary, we are simply looking forward to it, but seeing its present polonization, we have strong doubts whether the handful of Lithuanian Vilniusites will ever be able to depolonize Vilnius to such a degree that it could actually be called a Lithuanian city..."23. Very typical in this context was one of the demands of the Lithuanian Christian Democratic Party published in "Vilniaus žinios" immediately after the Congress: "efforts should be made, to establish a Lithuanian university in Lithuania" 24 , that is: not necessarily in Vilnius. This tendency, however, failed to win priority even among the Lithuanian Cristian Democrats. Without going into greater detail it can be noticed that, by rejecting Vilnius, Lithuanians would actually be abjuring their tradition of statehood, not to mention their ethnic lands. The fact that this would mean disregarding the GDL's political legacy, is clear from a statement in the latter article: "Kaunas has produced Valančius, Baranauskas and many other defenders of our nation...". What matters here is not just that these two activists were bishops but also that they contributed most to the Lithuanian nation in the ethnolinguistic

${ }^{20}$ E. Aleksandravičius, op. cit., 162.

${ }^{21}$ Senelis Lietuvis [kun. J. Ulickis], Kaunas ir Vilnius, Nedeldienio skaitymas, 44, 1907, 345-346.

${ }^{22}$ Senelis Lietuvis [kun. J. Ulickis], Kur dabartinès Lietuvos centras: Kaune ar Vilniuj?, ibid., 48, 1907, 19-20.

${ }^{23}$ Ibid., 20.

${ }^{24}$ Atbalsiai Vilniuje, Vilniaus žinios, 278, 1905. 
sense and were not really political activists (most of whom were connected with Vilnius).

However, dealing with this problem on the level of potential, the chances of Kaunas getting a higher school do not end here. The point is that Russia was faced with a chronic shortage of specialists with higher education, so from time to time the authorities were considering the issue of establishing new higher schools. For intance, the officer in charge of the Vilnius educational district noted in 1904 to the Lithuanian Minister of Education that every major city of Russia (he mentioned Vilnius, Vitebsk, Mogiliov and Minsk) should be permitted to fund the establishment of a higher school. Should such an institution be maintained by the state, the location ought to be selected by the government according to need ${ }^{25}$. True, he did not mention Kaunas, yet this can be explained by the fact that unlike the above mentioned towns, in the early 20 th century Kaunas had not appealed to the government with a similar request. Naturally, in that case Kaunas' turn would be after Vilnius. It is known, however, that there were officials in the Russian administration who believed that the Russian influence in the so called North-West territory could be neutralized by raising the Lithuanians' self-consciousness, thus bringing these two nations into oposition. The officer in charge of the Vilnius educational district, V. Popov, divided it into two parts according to the ethnographic principle: that of Minsk (Belorussian) and that of Vilnius (Lithuanian). Should the above tendency win among the Russian administrative circles, in the so-called Lithuanian district the priority could also be taken by Kaunas which was less influenced by Poland.

Indeed one can agree with the judgement of historians that the Lithuanian Learned Society (LMD) was to prepare the ground for a university. The Society was concerned not only with research but also with teaching. For instance, it organized a textbook competition. The Society tried to make up for the absence of a university in Vilnius by organizing public courses ${ }^{26}$. However, the issue of establishing a university or some other higher school was not recorded in the minutes of either Board meetings or general meetings of the LMD during the Russian occupation.

Such a possibility, however, cannot be totally excluded, as minutes were taken in Russian and were available to the local authorities. Therefore they, in particular the minutes of Board meetings, may not have recorded everything. On the other hand, the LMD united practically all active intellectuals of Lithuania. Therefore every time the question of restoring Vilnius University or founding some other higher school was raised, LMD members also had their own say - in

${ }^{25} 1904 \mathrm{~m}$. balandžio 19 d. Vilniaus švietimo apygardos globèjo rašto liaudies švietimo ministrui kopija, LVIA f. 378, BS, ap.116 (1908 m.), b.340, 1.28.

${ }^{26} 1909 \mathrm{~m}$. liepos $15 \mathrm{~d}$. LMD Valdybos posédžio protokolas, - The Institute of Lithuanian Literature, Manuscript section, f. 22, b. 2, 68. 
capacity as the members of the society, or not. And the LMD itself could not raise this question for another reason - that it did not have the necessary funds. It made attempts to draw financial aid from the government for the running of the society.

\section{A Polish University}

There is no doubt that the Poles of Lithuania were also trying to found a national (Polish) university. For instance, the statutes of the Polish educational society "Oświata" (Education) contained a clause that the Society would engage in the foundation, maintenance and support of a variety of secondary and higher schools ${ }^{27}$. On the other hand, it was clear that the Poles in Vilnius had by far the biggest intellectual powers. However, in the course of 1905-1907 the idea of a national university was raised very rarely. Such a situation could be accounted for by several factors. First and foremost, they realized very well that the authorities would not permit the founding of such a university, and a Russian university would hardly make sense when higher education could be received at the Polish universities of the Austro-Hungarian Empire (Cracow, Lvov). On the other hand, a Lithuanian university could be even more convenient to them than a Polish one. The reason was that as soon as a Polish university was established the other nations of the ethnic GDL lands would demand similar national universities. Moreover at a common university the Poles, outweighing the others in their intellectual potential, would be able to preserve and expand their influence on the Lithuanians, Belorussians and so forth. One more interpretation is possible. At least the elections to the Russian Dumas in Lithuania, especially in Vilnius, show that during the Revolution of 1905 the National Democratic orientation among Poles of Lithuania was much weaker than afterwards.

Without any doubt, the ground for such a Polish university had to be prepared by the Association of Science Fellows (MBD). However, like in the case of LMD, throughout the period since the establishment of the Association until the end of the Russian occupation this question had not been on the agenda of either general MBD assemblies or Board meetings. In this case, however, the stipulations were the same as those of LMD.

\section{A Lithuanian University}

In its issue of January 31, 1906 "Novoye Vremia" (New Age) wrote that for over a month rumours had been spreading that allegedly the Lithuanian Ministry of Education was drafting a plan under which all state-maintained schools of the Polish Kingdom would introduce Polish as the language of instruction, and that the University of Warsaw would become Polish (i.e. with Polish as the language of in-

${ }^{27}$ Ustawa Polskiego Towarzystwa "Oświata" w Wilnie, Vilnius, 1906, LVIA, f. 378, ap.4, b.158, 1.52a. 
struction $)^{28}$. Thus this rumour must have originated at the very turn of 1905. Implementing such a policy would mean an essential change in the educational policy of the Russian government. Such information, like the total upsurge of the Revolution late in 1905 was to stir also those activists who were concerned with the issue of reopening Vilnius University.

Late in November 1905 a meeting of Lithuanian and Polish intellectuals was held in St. Petersburg, headed by Prof. Jan Baudouin de Courtenay ${ }^{29}$. Although it was the Professor himself who maintained that the idea of a university had been born in Vilnius and its outskirts, the proponent of this idea in St. Petersburg was Antanas Medeksza ${ }^{30}$. As far as is known, apart from Prof. Baudouin de Courtenay, the meeting was also attended by professors from St. Petersburg University (John and Stanislas Ptaszycki), from the Theological Academy (Prof. Kazimieras Jaunius, Aleksandras Dambrauskas (Jakštas), Jonas Maciulevičius (Maironis) and by J. Ziemnacki, a professor of surgery from the Duchess Helen Institute. These persons signed the declaration which established the society. It is also known that A.Medeksza and the engineer Jaczewski also took part in the meeting.

Was this meeting of Lithuanian and Polish intellectuals not linked with the political processes occurring in Lithuania itself? It was precisely in November 1905 that the programme of the LBKKP was being drafted. And this party, as mentioned above, sought to unite all people of the former GDL lands under one flag. There is no direct evidence to support of this opinion, but, one circumstance is worth attention. The LBKKP programme was signed by V. Mironas, a Christian Democrat, who subsequently participated at the party's constituent assembly $^{31}$. And the latter meeting in St. Petersburg was attended by all professors of the St. Petersburg Theological Academy, without exception, and furthermore A. Dambrauskas and J. Maciulevičius (Maironis) were the authors of the agenda of "The Lithuanian Christian Democrats Association". Therefore an assumption can be made that the nascent political organization, apart from seeking to unite all citizens of the GDL lands, was also involved with the foundation of a higher school. Incidentally, in the initial stage of the LBKKP development one can easily envisage an intention, as soon as the political status quo is changed, to seize local power ${ }^{32}$.

The article by A. Medeksza in St. Petersburg newspaper Kraj in early 1906 suggests that during that meeting Jaczewski reviewed the existing types of free universities; a question was also raised whether or not the Lithuanians would be able to mobilize the required aca-

${ }^{28} \mathrm{P}$. Kulakovskii, Vopros o Varshavskom universitete, Novoye vremia, 10734, 1906.

${ }^{29}$ A. Medeksza, Litwa i Ruś. W sprawie uniwersytetu w Wilnie, Kraj, 2, 1906, 14.

${ }^{30} \mathrm{~J}$. Baudouin de Courtenay, Uniwersytet w Wilnie, ibid., 1, 1906, 5.

${ }^{31}$ Ibid.

${ }^{32}$ D. Staliūnas, Vilniaus vyskupo E.Ropo veiklos pèdsakais (1903-1907), in LAIS, VII: Atgimimas ir Kataliką Bažnyčia, Vilnius, 1994, 178. 
demic potential to hold lectures. A.Dambrauskas gave a positive answer. The issue of funds was also heard. Here again Jaczewski declared that a cultured nation would not grudge expenses for such a noble purpose ${ }^{33}$. It is most likely that this declaration was passed in late 1905 at St. Petersburg and published in the Vilnius papers, as there is no knowledge of its having been revised. One would think that, if the declaration had been altered, J. Baudouin de Courtenay would have reacted to it one way or another in his article "A University in Vilnius", published in the newspaper Kraj on January 6, 1906, in which he explained some of the circumstances surrounding the declaration's origin ${ }^{34}$.

The declaration was written in both Lithuanian and Polish. It was printed in the Vilnius newspapers Vilniaus žinios and Kurjer Litewski $i^{35}$. The declaration began in the following words: "We, the undersigned, undertake the initiative of establishing a "Society for the Establishment of a Free University" in Vilnius with Lithuanian, Polish and other national languages used in instruction, so that educated people of all nationalities may have access to knowledge". Furthermore the declaration pointed out the practical steps which were to be taken: to found a society with a residence at Vilnius, to convene "a general assembly of University fellows" which was to draft the society's statute and elect a board. What followed looked like an oath: "The undersigned promise to use every means and effort in defending the cause of establishing a free university in Vilnius and not to dissolve until this idea is brought to life". The declaration was supplemented by a proclamation. Above all, it indicated that "Lithuania had long enjoyed the right to establish a university in Vilnius. A highly important fact in this proclamation is the naming of the major addressee: "The initiators of the foundation of the "Society for the Establishment of a Free University in Vilnius" consider it their duty to appeal to "all our citizens, notwithstanding their nationality and faith" (my emphasis). Therefore this university would be oriented towards the needs of the entire population of historic Lithuania. However, another passage in this proclamation, appealing for the organization of support groups, only called upon Poles and Lithuanians. Therefore it becomes clear that the needs of Lithuanians and Poles were a primary concern. The declaration, too, was signed only by the representatives of these two nationalities. Had there been a will, both in St. Petersburg and in Vilnius, a suggestion to sign this declaration could have been made also to the Jews, Russians and Belorussians. There can be no doubt that individual representatives of these peoples would have signed as well.

${ }^{33}$ Medeksza, "Litwa i Rus. W sprawie uniwersytetu..."

${ }^{34}$ Baudouin de Courtanay, op. cit., 2-6.

${ }^{35}$ Inicijatoriai. Universitetas Vilniuje, Vilniaus žinios, 290, 1905; Uniwersytet w Wilnie, Kurjer Litewski 87-92, 1905. Further quotations according to the Lithuanian version. 
The proclamation is also addressed not only to all citizens, but also to newspaper editorial boards separately, so that everyone would offer moral support to the "initiators' goals", spread the news about this action and form groups. By the way, the proclamation does not give a broader grounding of the necessity for a university in Vilnius. Just one reason is pointed out - that currently the youth is compelled to seek education in remote lands.

In Vilnius this declaration was also signed by the prominent Lithuanian scholar Jonas Jablonskis, the engineer and publisher of the Lithuanian press Petras Vileišis, a co-proprietor of a print shop F. Zawadski, the afore-mentioned A. Medeksza, M. Burchard and J. Szwański. It is not clear whether they signed after some meeting or whether each of them had been invited to sign separately.

So what kind of a university was it supposed to be? Its very name shows it would not be a state institution, as is also proved by the appeal for funds, although the appeal would not in itself mean that this was going to be a publicly maintained and controlled institution. For instance, when the issue of a higher school had first been raised in the early years of the 20th century, the plans were that monies collected publicly for the foundation of a higher school would be placed at the government's disposal. Obviously, the evolution of a "Free University" had to depend on concrete financial, political and other circumstances... Besides, one can guess that the signatories held different views of the university's evolution. It should be noted here that Baudouin de Courtenay supposed that the society for the establishment of a university in Vilnius was to develop into an educational society in the broadest sense and to engage in the spread of knowledge all over the country, and that along with the "Free University" a People's University would to be established. The latter would travel across the country and would offer instruction in all languages, even Belorussian, should there only be a popular desire and trained lecturers ${ }^{36}$.

Society, Lithuanian in particular, showed a rather lively and favourable reaction to this idea. At the beginning the participants of the St. Petersburg meeting themselves specified their position, described the circumstances of the foundation, speculated on the real possibilities of reopening the university. Jaczewski declared that he had been present at the consultations in St. Petersburg but had not signed as he did not approve of the procedure drafted by A. Medeksza for a university in Vilnius. Besides, first of all it would be necessary to end Lithuanian-Polish disputes, and only afterwards to speak of a higher school ${ }^{37}$.

Baudouin de Courtenay gave a wider coverage of his attitude in the previously mentioned article of Kraj. The professor had a clear

${ }^{36}$ J.Baudouin de Courtanay, op. cit., 5-6.

${ }^{37} \mathrm{O}$ uniwersytecie w Wilnie, Kurjer Litewski, 10, 1906. 
realization that a normal university would be able to function only if the empire itself were transformed... In his opinion, "the state ought to be supranational (Pol. "pozanarodowościowy") and ought only to foster economic and general political ties between separate ethnic groups (nations)". He went on to say that it was necessary "to reject once and for all the perilous dream of the nation state and throw out the short-sighted egotist slogan: "Russia for the Russians", "Poland for Poles", "Lithuania for Lithuanians" etc. Russia should be for everyone who lives in her, Lithuania for all those who dwell in her, etc" ${ }^{38}$. Such a commitment to political consolidation was very much favoured by the krayowcy democrats. As regards the definition of the state's functions, Baudouin de Courtenay's views were closely shared by $\mathrm{T}$. Wróblewski ${ }^{39}$. One can say that Baudouin de Courtenay formulated the objectives of the Polish people very much in the way the krajowcy did: "Whatever the case, in the domain of cultural and national work it would be enough for the Poles to concentrate on real Poland and on the truly Polish section of the population (ludnosci istotnie polskiej), similarly, the Russians should be satisfied with the education and cultural improvement of the genuinely Russian part of the population. Any attempts directed at removing separate national identities are just a waste of energy as well as a demoralizing and stupefying measure. The Poles should once and for all abjure polonization and the thought of playing the role of "older brother" in Lithuania, Belorussia, the Ukraine and the other parts of the former Commonwealth. It is sufficient to demand general civil rights and the ending of attempts to remove separate national identities on all sides". He believed that the languages of instruction should be Polish, Lithuanian and Russian (for the Belorussians). As an example, he pointed at Finland and Switzerland ${ }^{40}$.

In the meantime, however, such a university was just a dream. A different thing was a free university with "free and open" access. Having reviewed the existing types of such universities, the professor delineated the aims of this kind of university including "the training and development of "political workers and conscientious citizens of the land"41. And the role of the language of instruction at such a university could be granted to "all languages of the world". As to the Lithuanian language, Baudouin de Courtenay was rather optimistic. He believed that this language was known by far more potential teachers than it might "seem at first sight" 42 . However, at the end of his article the author noted that the establishment of even such a university was just a dream ${ }^{43}$.

${ }^{38}$ Baudouin de Courtenay, op. cit., 3 .

${ }^{39} \mathrm{D}$. Staliūnas, Tvirtai tikèjęs vieningos europietiškosios kultūros ateitimi. Tadeuszo Wróblewskio idejjinès-politinès minties evoliucija, Kultūros barai, 4, 1994, 55-58.

${ }^{40} \mathrm{~J}$. Baudouin de Courtenay,op. cit., 3-4.

${ }^{41}$ Ibid., 4-5.

${ }^{42}$ Ibid., 5 .

${ }^{43}$ Ibid., 6. 
Baudouin de Courtenay's article was reprinted by Vilniaus Žinios ${ }^{44}$ and Kurjer Litewsk ${ }^{45}$.

This idea was received favourably by the Lithuanian press. The article, published by Vilniaus Žinios on January 8, in principle approved the opinion that the university had to meet the needs of the whole Lithuanian population. Therefore the university's "establishment should involve all estates of the realm, all nationalities living in Lithuania'. And further on: "It will be up to the commission to arrange everything in such a way that not a single nation would feel neglected and that all of them should be catered for'. In the author's opinion, only such a university could resist governmental pressure ${ }^{46}$. Another writer from Vilniaus Źinios proposed starting to collect funds for the future university: "Let us hurry or we shall be left behind; I think that if the Lithuanians offer too little assistance (less than the Russians, Poles, Jews), only some ten-fifteen thousand, we will have to wait a long time before "some" Lithuanian department or other is established". However, it follows from this article that the author viewed such an option only as a temporary measure. The main objective was "A Free Lithuanian University"47.

In the meantime, Z. Žemaitis expressed open doubts concerning the vitality of such a university. Tuition in three or four languages could provoke conflicts. Therefore he proposed to wait for a couple of years, and to establish primary schools now. While later on "we shall be able to found a separate, purely Lithuanian university" 48 . Such a university has already been discussed in the present article.

Similarly also the Poles, even the founding fathers, dwelling on the future of a "Free University", would soon betray that they were primarily concerned with a national Polish university: "The Poles would certainly not miss the opportunity to gather their dispersed forces and would use them as a basis for a higher school in Vilnius" ${ }^{\prime 4}$.

There were those among the Jews who would also approve of the idea of this kind of university. A conflict even arose between Kurjer Litewski and Jewish newspaper Novaya Zarya. The Jews were trying to prove that they, too, were fully entitled to the fruit of such a university - should the university be established on local state funds, why should the Jews be worse off, on private ones - the Jews were also ready to sacrifice ${ }^{50}$.

The only known attempt to establish a support group for such a university was in Raseiniai. The meeting held on Dec. 28, 1905 was attended by "all classes of the local population". The same kind of a declaration was signed at the assembly, only it was added that beside

\footnotetext{
${ }^{44}$ Z. Žemaitis, Dar prie Vilniaus universiteto, Vilniaus žinios, 45, 1906.

${ }^{45} \mathrm{O}$ uniwersytecie w Wilnie.

${ }^{46}$ K.P. [?], Vilniaus universitetas, Vilniaus žinios, 8, 1906.

${ }^{47}$ M.U. [?], Rinkime aukas Lietuvos reikalams, ibid., 19.

${ }^{48} \mathrm{Z}$. Žemaitis, Prie Vilniaus universiteto.

${ }^{49} \mathrm{~A}$. Medeksza, W sprawie uniwersytetu.

${ }^{50}$ A.K. [?], K Vilenskomu universitetu, Novaya Zarya, 57, 1906.
} 
the instruction languages of Polish and Lithuanian there should also be the Belorussian language. A decision was made that the society's annual membership fee would be three roubles. However, the society's foundation was postponed until February ${ }^{51}$. It seems that at this point the intentions of Raseiniai came to an end.

Thus, the possibilities for the establishment of a "Free University" had hardly been discussed before, quite different views of the concept arose, even among the would-be founding fathers. On the other hand, despite the fact that the actual reactions of both - the local and central government to this idea are not recorded, their position can be easily guessed. In a similar way the establishment of the chair of Lithuanian language and history with the Lithuanian as the language of instruction in the University of Warsaw was feared. According to the newspaper Dziennik Wilenski, the Ministry of National Education turned down this application for fear that the same request could be made by the Belorussians. The point was that in such a case Polish, Lithuanian and Belorussian intellectual life would concentrate in one place and this would go counter to the interests of the state ${ }^{52}$. This news was repeated by Vilniaus Žinios ${ }^{53}$. Therefore the Russian administration did not spare efforts to block the cultural integration of the nations dwelling in the historic lands of the GDL, especially among their elite.

\section{A University in Lithuania}

At the peak of the Revolution, late in 1905, the prevailing ideas were those of a national or Lithuanian university; during the early part of 1906, however, and in 1906-1907 a more widely discussed possibility was that of a university with Russian as the language of instruction. This meant orientation not to the actual state of affairs, but to a more distant future.

For instance, one of the writers of "Vilniaus žinios" speaks in favour of a university, even if it is "not completely ours, let the language in it be foreign", for ever such a university "will be a source of knowledge; science will remain science anyway and, whatever the case, it will serve our needs". As to the language of instruction at such a university, the newspaper's editorial staff added its own postcript: "A chair of Lithuanian language will suffice" ${ }^{4}$. The speculations of the Lithuanian-Polish democratic activist, L. Abramowicz, about the possible establishment of a university in the "North-Western provinces" suggest that he would not be against the establishment of such a university in Vilnius. As a matter of fact, he opposed the establishment of a university in Minsk and Vitebsk with Russian as the lan-

${ }^{51}$ Iš Lietuvos. Raseiniai. Draugija Liuoso universiteto Vilniuje, Vilniaus žinios. 2, 1906.

${ }^{52}$ Wiadomości bieżące. O katedrą języka litewskiego, Dziennik Wileński, 9, 1906.

${ }^{53}$ Atbalsiai Vilniuje. Apie lietuvių kalbą universitetuose, Vilniaus žinios, 200, 1906.

${ }^{54}$ V. Karuža [J. Jasaitis], Universiteto Vilniuje reikia, ibid., 85. 
guage of instructions, and the professors and students coming from Russia. He believed that such an institution both in Minsk and Vitebsk would serve as a fine tool of Russification, for the local people there would easily submit to such influence. Abramowicz also thinks that in the future the time will come for a Belorussian university in Minsk as well, although he did not outline this idea. For the present Belorussia needed primary schools and elementary education ${ }^{55}$. Also the author of an article printed in the Jewish newspaper SeveroZapadnyj Golos presumed that the best solution would be to transfer the University of Warsaw to Vilnius ${ }^{56}$ (the issue of the transfer of this University to another city of Russia is discussed below).

As the revolution subsided, practical steps were also taken in the direction of the foundation of such a university. On September 10, 1906 Vilnius newspapers Kurjer Litewski, Dziennik Wilenski and Vilniaus žinios reported that the Russian news agency wrote from St. Petersburg, that before long a draft for the establishment of Vilnius University would be confirmed ${ }^{57}$. A couple of days later, on September 14, Vilniaus žinios announced that the question of the foundation of the Girls' Higher Courses would be discussed at the private meeting of the Vilnius city council ${ }^{58}$. Again, according to Kurjer Wilenski, which published the news on September 19, the opening of such courses in Vilnius was being considered at the National Education Ministry 59

This time, the initiative was already being taken by the Vilnius city authorities. At the meeting of the Vilnius Duma on December 7, 1906 the authorities introduced the draft of the establishment of the Higher Courses for Girls. In introducing these courses the council noted that the issue of a higher school, with the approval of the local administration, had been brought up repeatedly by the public. In the council's opinion, it was possible to expect financial aid from the government; a part of the funds would be supplied by the city and additional funds provided by the tuition fee. The idea was approved by the head of the municipality of the city M. Węsławski. However, one member of the council J. Januszewski suggested that the establishment of a university should be a priority. He was backed by some other members of the council. The rest of the council, including M. Węsławski, spoke against the establishment of a university. It was pointed out that the price of a university would exceed that of any other type of higher school, and besides, the government would not permit the foundation of a university. Eventually a decision was made to set up two commissions: one for the Higher Courses for Girls, the other - concerning the foundation of a university. Another decision

${ }^{55}$ L. Abramowicz, Dwie strony medalu, Kurjer Litewski, 17, 1907.

${ }^{56}$ P.S. [?], Universitet v Vilne, Severo-zapadnyj golos, 299, 1906.

${ }^{57}$ Kronika krajowa. Wilno. Uniwersytet w Wilnie, Kurjer Litewski, 204, 1906; Wiadomości bieżące. Uniwersytet w Wilnie, Dziennik Wileński, 8, 1906; Atbalsiai Vilniuje. Universitetas Vilniuje, Vilniaus žinios, 199, 1906.

${ }^{58}$ Atbalsiai Vilniuje. Aukštesnieji Mergaičiu kursai, ibid., 202,1906.

${ }^{59}$ Kronika Wilenska. Wyzsze kursy żenskie, Kurjer Litewski, 211, 1906. 
was to involve as many public representatives who could contribute to the solution of this question as possible in the work of these commissions. The members of these two commissions were elected at the next meeting of the Duma, held on December $20^{60}$.

This was the end of the action of the municipality of Vilnius. It is known for sure that until the very beginning of 1908 the national Education Ministry had not received requests concerning the foundation of a university in Vilnius ${ }^{61}$. There is no information about the work of either of the commissions. We shall attempt to explain this situation in the next section.

\section{The Attitude of the Russian Administration}

to the Establishment of New Universities

During 1905-1907 the central government did not consider any public requests concerning the foundation of a university in Vilnius, for, as has been mentioned above, until the beginning of 1908 St. Petersburg had not received any applications on this issue. However, the government could have taken such an initiative itself. Similar projects are well known from the mid-19th century.

During the revolt of 1905 several rumours were heard about a prompt establishment of a university in Lithuania too. For instance, on June 29, 1905 Vilniaus žinios wrote: "The minister of public education has already put forward an idea for the establishment of a university in Lithuania..." 62 ; a stronger rumour, only about the actual readiness of the government to establish a university in Vilnius, was heard, as we have mentioned, in September 1906.

The question of new universities and other higher schools, which arose continually in the early 20th century, was being considered by the central government during the revolution period too. It seems, however, that the Russian government had most troubles not with the establishment of a new university, but with the University of Warsaw which already existed. On January 28, 1905 the students of the University went on strike, and officially the university was closed on April 3 the same year. Certain intellectual forces and financial resources were being wasted. Therefore various strata of the Russian administration began to consider the possibility of moving the University of Warsaw to another city the Russian Empire. In view of the fact, that it was Vilnius that in the early years of the 20 th century had shown the greatest initiative for establishing a higher school, and bearing in mind the role of Vilnius as the cultural, administrative and, in a sense, economic centre of "Northwest Russia" (which did not possess a

${ }^{60}$ Zurnal vilenskoi gorodskoi dumy za vtoroe polugodie 1906 goda Vilna, 1909, 261-263, 299-300; Feliks [?], Z rady miejskiej, Dziennik Wileński, 85, 95, 1906; Atbalsiai Vilniuje, Vilniaus žinios, 283, 1906.

${ }^{61}$ National Education Minister's note to the Governor General of Vilnius, March 17, 1908, LVIA, f.378. BS. 1908, ap., b.340. 1.14. 1905

${ }^{62}$ B.V. [A. Rucevičius], Rüpinkimès ịsteigti universitetą Vilniuje, Vilniaus žinios, 157, 
single higher school) and, finally, remembering that it was Vilnius which in the first half of the 19th century had by far the most solid university of the Empire, one can assume that a positive or negative decision to transfer the University of Warsaw to Vilnius was, above all, a political move. In other words, the question was, whether or not the government considered itself to be able to use its russification powers to overcome the "Polish" influence in "Northwest Russia".

It ought to be noted at once that the establishment of a university or any higher school with government funds was strongly opposed by V. Popov, the officer in charge of the Vilnius Educational district. While in 1902-1903 he had not opposed Higher school of agriculture in Vilnius, during 1904-1905 he was very resolutely opposed to setting up such an institution. In 1905, reiterating his thoughts voiced during his presentation to the Minister of National Education he proposed establishing no university even in Minsk. He supposed that it would be best to found a university in Vitebsk. However, as in the previous years, the officer in charge of the Vilnius educational district expressed a view that all major cities of the Empire should have a university ${ }^{63}$.

Already in spring 1905 one of the Board members of the University of Warsaw had visited Saratov and negotiated with local officials about the university's transfer there ${ }^{64}$. In November of the same year most probably someone from the University of Warsaw professorial staff drafted a "Report on the Current State of the University of Warsaw", addressed to the Prime Minister Witte. The report spoke in favour of the temporary use of the intellectual potential of the University of Warsaw in some other part of Russia ${ }^{65}$.

As all Russian universities were closed due to strikes, the conference of university rectors held in St. Petersburg in August 1906, approved the temporary closure of the University of Warsaw ${ }^{66}$. Polish sholarship maintains that after this conference the Board of the University of Warsaw spoke for the university' moving to another city of the Russian Empire ${ }^{67}$, but not, of course, to a city of the Polish Kingdom.

The finishing touches in solving the fate of the University of Warsaw were put by the Council of Ministers on October 20, 1906. Having considered the conclusion of the Board of the University of Warsaw that once a Russian university had been founded in Warsaw, it was to remain there, and the potential of the university could provisionally be employed in another place of Russia ${ }^{68}$.

${ }^{63} 1905$ m. gruodžio 22 d. Vilniaus švietimo apygardos globèjo rašto Liaudies švietimo ministrui kopija, LVIA, f.378. BS, ap.116, 1908 m., b.340, 1.29-33.

${ }^{64} \mathrm{H}$. Kiepurska, Uniwersytet Warszawski w latach 1899-1915, in Dzieje uniwersytetu Warszawskiego 1807-1915, oprac. Kieniewicz, Warszawa, 1981, 518.

${ }^{65}$ Ibid.

${ }^{66}$ L. Zembruski, Cesarski uniwersytet Warszawski i jego mydziat lekarski 1905-1915, Warszawa, 1939, 13.

${ }^{67}$ Ibid.

${ }^{68}$ Ibid.; P. Kulakovskii, Kak otkryt' Varshavskii universitet?, Novoye vremia, 11041, 1906. 
Obviously, society was not informed at once of this resolution made by the Council of Ministers, for there were still efforts to plead for the transfer of Warsaw University to Minsk. A private meeting of the Minsk city Duma was held on November 27 to discuss the appeal to move the University to Minsk. It sent a telegram to the University of Warsaw asking whether it would be sufficient if the city granted it 500.000 roubles and some land. A positive answer was received ${ }^{69}$. A general meeting of the Minsk Agricultural Society, held on December 10 , also raised this question. When a suggestion was made to transfer the university not to Minsk but to Vilnius, the city head Stefanowski explained that Vilnius was not on the list of the cities in which the government was planning to establish a university, therefore, the position being such, a university will be founded either in Samara or Voronezh. Such explanations produced an effect on landlords who decided to support the initiative of the city administration ${ }^{70}$.

At the same time a decision was made to form a special commission dealing with the establishment of a new university in Russia. On November 22 such a commission was confirmed by the Minister of national Education. The commission considered the nominations of Minsk, Vitebsk, Nizhny Novgorod, Voronezh and Smolensk (other sources mention Saratov). These cities promised various amounts of money (from 500.000 to 1.200 .000 roubles). However, this factor did not tell on the commission's decision. The fact was that the money would be insufficient, and besides, different cities would need different sums of money. The first to be declined were the nominations of Minsk, Vitebsk and Smolensk, as they were more poorly equipped with the technical basis for the faculties of medicine. According to the commission's calculations, at the outset a university would need 1.800.000 - 2.500.000 roubles. Plans were made to open a new university in stages over a period of 5 years, i.e. by $1912^{71}$. The final chance was Saratov. Vilniaus žinios carried information on this decision of the Council of Ministers on June 8, $1907^{72}$. The university in Saratov, or rather just the faculty of medicine, was founded on June, $1909^{73}$ Thus the so-called "Northwest Provinces" were once again left without any higher school.

\section{Afterword}

Czesław Miłosz once voiced the following thought: "One perfectly bilingual or even trilingual - including Belorussian - school would have been enough to raise a generation of Lithuanian patriots,

${ }^{69}$ P.S. [?], Universitet v nashem kraye, Severo-Zapadny golos, 299, 1906.

${ }^{70}$ Vilenskiye vesti. Ob universitete v nashem krae, ibid., 317, 1906; Atbalsiai. Kitur. Apie universitetą Lietuvoje, Vilniaus žinios, 288, 1906.

${ }^{7}$ Uchebnoe delo, Vecherniye pribavlenia $k$ Pravitelstvennomu vestniku No3 1907; Vopros ob otkrytii universiteta, Severo-Zapadnyi golos, 327, 1907; P. Kulakovskii, Byt' li universitetu v Varshave i kogda yego otkryt'?, Novoye vremia, 11106, 1907.

${ }^{72}$ Kitur. Naujas universitetas, Vilniaus žinios, 87, 1907.

${ }^{73}$ L.Bazylow, Ostatnie lata Rosji carkkiej. Rzady Stolypina, Warszawa, 1972, 321. 
ignorant of linguistic conflicts, with a good command of several languages. After 1918 this would have lead along the Finnish road"74. We will note that Milosz does not mention a bilingual (trilingual) university. And this is understandable. People coming to a university have well-shaped outlooks. Therefore the establishment of a Free University with instruction in Lithuanian, Polish and other languages of the historic peoples of the GDL during the Revolution of 1905 would hardly in itself have corrected the ethnopolitical tendencies in Lithuania. However, it might have reduced Lithuano-Polish antagonism. The point is, that after the insurrection of 1863 the Lithuanian nobility, under the conditions of the Russian policy of "depolonization", was unable to develop any solid illegal cultural activities. Therefore the Lithuanian nobles became consumers of literature published in the other parts of the former Republic of the Two Nations. And not only this. Owing to the absence of a university in Vilnius, they would go to study in other institutes of higher education. It was exactly during the latter half of the 19th century that Cracow, with its university and other scholarly, cultural and educational institutions became the centre of Poles and Polishness. It is common knowledge that Poland essentially viewed Lithuania as a Polish province. Thus, education in Polish higher schools, to put it midly, could have hardly contributed to the Poles having a more favourable opinion of the goals of ethnic Lithuanians. Meanwile, the whole pleiad of Lithuanian intellectuals received its education at Russian universities whose anti-Polish orientation played a significant role in their formation. However, the role of the possible Vilnius University in reducing the antagonism between Lithuanians and Poles in the early 20th century should not be overestimated. The paths of Lithuanians and Poles had long been diverging. Let us draw an analogy - with the University of Prague. A state of peaceful coexistence between Germans and Czechs had never been achieved there, and in 1882 the university was divided into two sections: Czech and German. Early in the 20th century there could hardly have been conditions for the type of school mentioned by Milosz. The emergence of a bilingual or trilingual school, able to guide the developments in the historic lands of the GDL in the Finnish direction, might have been possible already in the mid-19th century. However, then, largely due to the Russian policies in the "Northwestern provinces", it did not become a reality.

${ }^{74}$ Cz.Miłosz, Kas toje Lietuvoje dejosi (Knygos "Tèvynès ieškojimas" skyrius), Kultūros barai, 8-9, 1993, 91. 